\title{
A Single Dose of Beetroot Gel Rich in Nitrate Does Not Improve Performance but Lowers Blood Glucose in Physically Active Individuals
}

\author{
Julia Vasconcellos, ${ }^{1}$ Diego Henrique Silvestre, ${ }^{2}$ Diego dos Santos Baião, ${ }^{1}$ \\ João Pedro Werneck-de-Castro, ${ }^{2,3}$ Thiago Silveira Alvares, ${ }^{4}$ and Vânia M. Flosi Paschoalin ${ }^{1}$ \\ ${ }^{1}$ Instituto de Química, Universidade Federal do Rio de Janeiro, 21941-909 Rio de Janeiro, RJ, Brazil \\ ${ }^{2}$ Instituto de Biofísica Carlos Chagas Filho e Escola de Educação Física e Esporte, Universidade Federal do Rio de Janeiro, \\ 21941-902 Rio de Janeiro, RJ, Brazil \\ ${ }^{3}$ Division of Endocrinology and Metabolism, Rush University Medical Center, Chicago, IL 60612, USA \\ ${ }^{4}$ Instituto de Nutrição, Núcleo Básico de Nutrição e Dietética, Universidade Federal do Rio de Janeiro, 27979-000 Macaé, RJ, Brazil \\ Correspondence should be addressed to Vânia M. Flosi Paschoalin; paschv@iq.ufrj.br
}

Received 11 October 2016; Revised 20 December 2016; Accepted 22 December 2016; Published 24 January 2017

Academic Editor: C. S. Johnston

Copyright ( 2017 Julia Vasconcellos et al. This is an open access article distributed under the Creative Commons Attribution License, which permits unrestricted use, distribution, and reproduction in any medium, provided the original work is properly cited.

\begin{abstract}
Background. Beetroot consumption has been proposed to improve exercise performance, since the nitrate content of this food is able to stimulate the synthesis of nitric oxide. Objective. The acute effect of $100 \mathrm{~g}$ of a beetroot gel containing $10 \mathrm{mmol}$ of nitrate was tested on the nitric oxide synthesis, on metabolic and biochemical parameters, and on performance in physically active individuals. Methods. Through a double blind, crossover, placebo-controlled study, 25 healthy runners ingested a single dose of beetroot and placebo gels. Participants performed an aerobic exercise protocol on a treadmill ( 3 min warm-up of $40 \%$ peak oxygen consumption, $4 \mathrm{~min}$ at $90 \%$ of gas exchange threshold I and $70 \%(\Delta)$ maximal end speed until volitional fatigue). Results. Urinary levels of nitrite and nitrate increased after $90 \mathrm{~min}$ of beetroot gel ingestion. Plasma glucose concentrations lowered after the exercise and the decrease was maintained for $20 \mathrm{~min}$. Systolic and diastolic blood pressures, serum cortisol, and blood lactate were not altered after the beetroot gel ingestion compared to a placebo gel. Conclusion. The single dose of beetroot gel provoked an increase of nitric oxide synthesis although no improvement on the physical performance of athletes during aerobic submaximal exercise was observed.
\end{abstract}

\section{Introduction}

The interest of the athletic population in sports nutrition as a way to boost physical performance has increased exponentially $[1,2]$. Several studies have been conducted on the influence of selective nutrition in improving the health and physical performance of individuals $[3,4]$.

One nutrient that is gaining prominence is dietary nitrate $\left(\mathrm{NO}_{3}{ }^{-}\right)$. Endogenous $\mathrm{NO}_{3}{ }^{-}$synthesis occurs through the Larginine/nitric oxide (NO) pathway. The nitric oxide synthase (NOS) enzyme alongside its cofactors catalyzes the formation of L-citrulline and NO from L-arginine. Once synthesized, $\mathrm{NO}$ is rapidly oxidized to nitrite $\left(\mathrm{NO}_{2}{ }^{-}\right)$or by ceruloplasmin and the $\mathrm{NO}_{2}^{-}$formed also can be oxidized or suffer action of oxyhemoglobin to generate $\mathrm{NO}_{3}{ }^{-}$. Furthermore, $\mathrm{NO}$ can react directly with oxyhemoglobin to generate $\mathrm{NO}_{3}{ }^{-}$[5-7]. Moreover, the major exogenous source for the acquisition of $\mathrm{NO}_{3}{ }^{-}$is via the dietary route. In a Western diet, most of dietary $\mathrm{NO}_{3}{ }^{-}$intake is obtained from vegetables [8].

Beetroot (Beta Vulgaris L. species) is a vegetable rich in nutrients, such as sugars, phenolics compounds, and ascorbic acid, and considered as a dietary $\mathrm{NO}_{3}{ }^{-}$source $[9,10]$. The $\mathrm{NO}_{3}{ }^{-}$ingested through the diet can be reduced to nitrite $\left(\mathrm{NO}_{2}{ }^{-}\right)$in the oral cavity by anaerobic commensal bacteria expressing the $\mathrm{NO}_{3}{ }^{-}$reductase enzyme, and the $\mathrm{NO}_{2}{ }^{-}$ formed can be converted to NO in blood and tissues through enzymatic and nonenzymatic pathways [11]. By stimulating $\mathrm{NO}$ synthesis, the $\mathrm{NO}_{3}{ }^{-}$from beetroot has been proposed as capable of restoring endothelial function $[6,12]$ and enhancing the blood perfusion [13] and performance in elite 
athletes [14-16]. For this reason, the dietary $\mathrm{NO}_{3}{ }^{-}$ingestion from beetroot, before athletic or sporting competitions, has become increasingly popular since it could be a legal and healthy way to enhance performance in elite athletes.

Several studies point to improvements in physical performance during endurance exercises, such as running and cycling, after the ingestion of $\mathrm{NO}_{3}{ }^{-}$in doses ranging from 5 to $16.8 \mathrm{mmol}[14,17,18]$. A significant increase in $\mathrm{NO}$ synthesis (evaluated by plasma $\mathrm{NO}_{3}{ }^{-}$and $\mathrm{NO}_{2}{ }^{-}$) associated with an increase in muscle contractile efficiency and reduction in $\mathrm{O}_{2}$ cost was observed. Additionally, an increased tolerable duration of moderate and severe-intensity exercises was also noticed. Taken together, these results indicate that dietary $\mathrm{NO}_{3}{ }^{-}$is capable of increasing the efficiency of the oxidative metabolic pathways to provide energy substrates for muscle contraction during exercise. However, the most positive results in physical performance were observed when the dietary $\mathrm{NO}_{3}{ }^{-}$supplementation from beetroot starts at approximately 6 days before the intervention [15, 19-21], while no effects were observed after a single dose of $\mathrm{NO}_{3}{ }^{-}$ supplementation [22]. There is still no consensus on the single dose effect from $\mathrm{NO}_{3}{ }^{-}$enriched-beetroot formula, except for juice administration in recreational athletes subjected to endurance test on a treadmill in sea level.

Dietary $\mathrm{NO}_{3}{ }^{-}$supplementation from beetroot is challenging with regard to the form of the beetroot administration. Foods in the gel form have certain technological advantages, such as being easy to store at room temperature, to carry and ingest, and to tolerate by athletes. Furthermore, gel foods tend to have higher concentrations of nutrients in a reduced volume, which favors greater access of the dietary nutrients to the cells [9]. In this context, the present study aims to analyze the biochemical and metabolic changes and effects on the performance of physically active individuals resulting from the ingestion of a single dose of nutritional beetroot gel rich in dietary $\mathrm{NO}_{3}{ }^{-}$, to evaluate the effects of this nutritional strategy on the practice of endurance sports.

\section{Methods}

2.1. Participants. Twenty-five healthy runners (11 women: $36.27 \pm 5.57 \mathrm{yr}, 58.19 \pm 3.54 \mathrm{~kg}, 26.13 \pm 4.38 \% \mathrm{BF}$, $52.79 \pm 4.57 \mathrm{~mL} \cdot \mathrm{kg}^{-1} \cdot \mathrm{min}^{-1} \mathrm{VO}_{2 \text { peak }}$ and 14 men: $35.36 \pm$ $6.59 \mathrm{yr}, \quad 73.50 \pm 8.27 \mathrm{~kg}, \quad 16.24 \pm 2.91 \% \mathrm{BF}, 64.31 \pm$ $4.71 \mathrm{~mL} \cdot \mathrm{kg}^{-1} \cdot \mathrm{min}^{-1} \mathrm{VO}_{2 \text { peak }}$ ) were enrolled in the study and classified as having an excellent $\mathrm{VO}_{2 \text { peak }}$ according to the American College of Sports Medicine (99\% percentile). The inclusion criteria were to be physically active and have more than one year of running experience, supervised by a physical educator. The exclusion criteria were any known cardiovascular, pulmonary, renal, and metabolic diseases, musculoskeletal injuries, use of steroids or nutritional supplements, smokers, intolerance or allergies to any of the beetroot, and/or the natural red dye components (Figure 1(a)). All participants were fully informed of the nature of the investigation and informed consent in accordance with Resolution number 446/12 of the National Health Council. All experimental procedures were performed in accordance with the ethical standards of Helsinki and approved by the institutional ethics committee (Hospital Universitário Clementino Fraga Filho, Rio de Janeiro, under number 21826513.3.0000.5257).

On the day before the visits, the participants were instructed to avoid the use of antibacterial mouthwash, intake of alcohol, caffeine, and foods rich in $\mathrm{NO}_{3}{ }^{-}$and $\mathrm{NO}_{2}{ }^{-}$for $24 \mathrm{~h}$.

2.2. Study Design. Participants performed 4 visits with seven days washout between the last two visits. During the 1st visit, participants were familiarized with the aerobic treadmill protocol and advised to fast for $8 \mathrm{~h}$ and follow their ordinary exercise training but avoiding intense exercise $24 \mathrm{~h}$ prior the 2nd, 3rd, and 4th visits. On the 2nd visit, the $\mathrm{VO}_{2 \text { peak }}$ of each participant was evaluated using an indirect calorimeter model CPX (VacuMed ${ }^{\circledR}$, CA, EUA) [23]. On the 3rd and 4th visits (Figure 1(b)), after overnight fasting, venous blood, urine samples and blood pressure values for the baseline measurements were collected. Subsequently, each participant received two single gels in black sachets with $50 \mathrm{~g}$ each of either beetroot-based nutritional (BET) or a placebo gel (PLA) and $300 \mathrm{~mL}$ of tap water. Subjects consumed $100 \mathrm{~g}$ of either BET or a PLA gel in a double blind, crossover, placebo-controlled and randomized experimental design within $15 \mathrm{~min}$. No adverse effects were reported.

2.3. Exercise Protocol. This aerobic exercise protocol performed on 3rd and 4th visits and $\mathrm{VO}_{2}$ collections performed on the volunteers of the BET and PLA treatments was carried out as previously described [14] but adjusted to treadmill (Figure $1(\mathrm{c})$ ). Ventilation (VE), inspired oxygen, and expired $\mathrm{CO}_{2}$ were measured during the treadmill run, and measurements were averaged over 10s intervals. Also, the respiratory quotient (RQ) was measured. The gas exchange threshold I (GET I) was determined using the V-slope method [24] as the first disproportionate increase in $\mathrm{CO}_{2}$ production $\left(\mathrm{VCO}_{2}\right)$ relative to the increase in $\mathrm{VO}_{2}$ and subsequently verified by an increase in the ventilatory equivalent for $\mathrm{VO}_{2}$ $\left(\mathrm{VE} / \mathrm{VO}_{2}\right)$, with no increase in $\mathrm{VE} / \mathrm{VCO}_{2}$. The test began with a 3 min warm-up at $40 \%$ of $\mathrm{VO}_{2 \text { peak }}$ followed by 4 min of moderate intensity at $90 \%$ of the GET I and a subsequent severe intensity to volitional fatigue at $70 \%$ of the difference $(\Delta)$ between $\mathrm{GET} I$ and $\mathrm{VO}_{2 \text { peak}}$, using the following equation:

$$
\begin{aligned}
& \text { Final speed } \\
& \left.\qquad \begin{array}{l}
= \\
\times
\end{array} \text { (maximum final speed in } \mathrm{VO}_{2 \text { peak }}-\text { GET I }\right) \\
& \times 70 \%]+ \text { GET I. }
\end{aligned}
$$

The rating of perceived exertion (RPE) measurements was performed by using an adapted Borg 0 to 10 point scale [25]. RPE were recorded at every minute after completing the warm-up stage.

2.4. Systolic and Diastolic BP and Heart Rate (HR). Three measurements of supine blood pressure of the brachial artery were taken using an automated sphygmomanometer (Cardiomed ${ }^{\circledast}$, Curitiba, BR) applied to the right arm after 


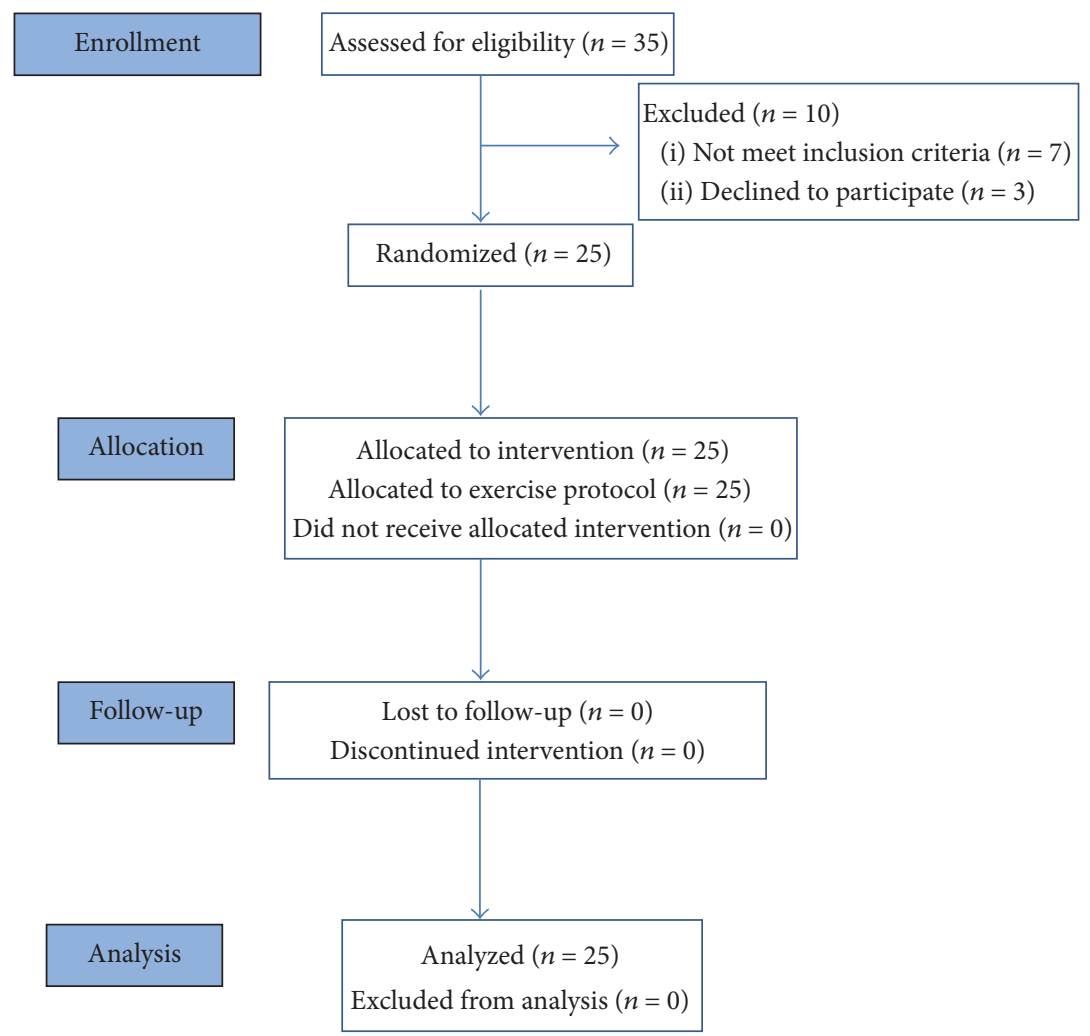

(a)

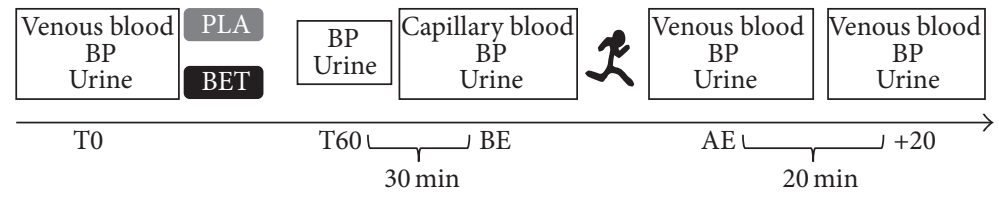

T0 - baseline

T60 - 60 min after gel ingestion

$\mathrm{BE}$ - Before exercise

AE - After exercise

$+20-20$ min after end of exercise
BP - Blood pressure

PLA - Placebo gel

BET - Beetroot gel

$\mathcal{k}$ - Treadmill exercise

(b)

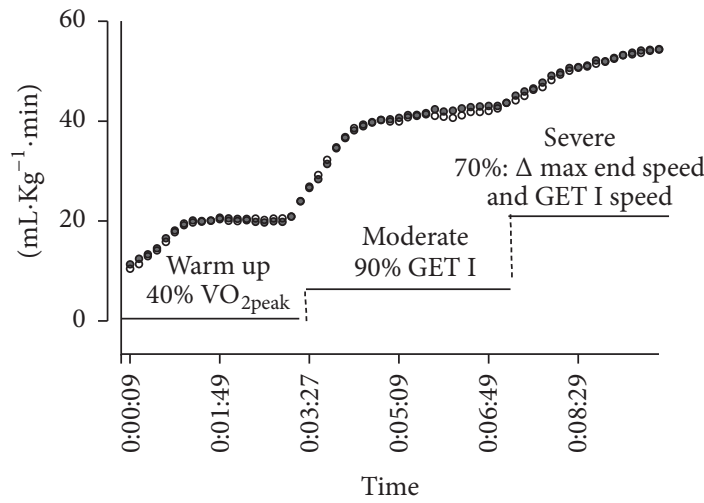

- PLA

- BET

(c)

FIGURE 1: Summary of the treadmill exercise protocol. (a) CONSORT flow diagram, (b) acute aerobic exercise protocol, and (c) $\mathrm{VO}_{2}$ collections performed on the $3 \mathrm{rd}$ and 4 th visits, of the BET and PLA treatment volunteers.

5 min rest. Exercise HR was measured during the test by a cardio tachometer, model T31 (Polar ${ }^{\circledR}$, Kempele, FIN). HR was recorded at every minute after completing the warm-up stage.

2.5. Blood and Urine Samples. Blood drawn from the antecubital vein was collected in tubes containing EDTA and a gel clot activator and centrifuged (at $1,500 \times \mathrm{g}$ for $10 \mathrm{~min}$ at $4^{\circ} \mathrm{C}$ ) to separate plasma and serum. The plasma was stored at $-80^{\circ} \mathrm{C}$ for subsequent analyses. Capillary blood was obtained by a transcutaneous puncture. Urine samples were taken in appropriate sterile containers, aliquoted, and stored at $-80^{\circ} \mathrm{C}$ for subsequent analyses.

2.6. Urinary $\mathrm{NO}_{2}{ }^{-}$and $\mathrm{NO}_{3}{ }^{-}$Analyses (NO Synthesis). Urinary $\mathrm{NO}_{2}{ }^{-}$and $\mathrm{NO}_{3}{ }^{-}$levels were determined as previously described [11] using a high-performance liquid chromatography (HPLC) system. Urine samples were diluted at a ratio of $1: 100$ for $\mathrm{NO}_{2}{ }^{-}$and $1: 2000$ for $\mathrm{NO}_{3}{ }^{-}$analysis in distillated and deionized water. Then, the samples were filtered through 
$10 \mathrm{kDa}$ cutoff ultrafilters (Vivaspin 500; $\mathrm{GE}^{\circledR}$ Healthcare Life Sciences; Uppsala, Sweden) at $14.000 \times \mathrm{g}$ for $15 \mathrm{~min}$ to remove high molecular weight proteins. For the $\mathrm{NO}_{2}{ }^{-}$ analysis, $100 \mu \mathrm{L}$ of filtered sample was incubated at $24^{\circ} \mathrm{C}$ with $10 \mu \mathrm{L}$ of $316 \mathrm{mmol} \cdot \mathrm{L}^{-1}$ of 2.3 -diaminonaphthalene (DAN) in $0.62 \mathrm{~mol} \cdot \mathrm{L}^{-1} \mathrm{HCl}$ for $10 \mathrm{~min}$ followed by the addition of $5 \mu \mathrm{L}$ of $2.8 \mathrm{~mol} \cdot \mathrm{L}^{-1} \mathrm{NaOH}$ and immediately analyzed by HPLC. For the $\mathrm{NO}_{3}{ }^{-}$analysis, $\mathrm{NO}_{3}{ }^{-}$sample was enzymatically converted to $\mathrm{NO}_{2}{ }^{-}$through the addition of $10 \mu \mathrm{L}$ of nitrate reductase (EC 1.6.6.2 Aspergillus species, Roche Diagnostics, Mannheim, Germany) and $10 \mu \mathrm{L}$ of $120 \mathrm{mM}$ NADPH (Roche Diagnostics, Mannheim, Germany). Then, the sample was incubated at room temperature for $1 \mathrm{~h}$. After conversion of $\mathrm{NO}_{3}{ }^{-}$to $\mathrm{NO}_{2}{ }^{-}$, this solution is used directly for the analysis of $\mathrm{NO}_{2}{ }^{-}$using HPLC system. The HPLC device was equipped with a $5 \mu \mathrm{m}$ reversed-phase C8 column (150 $\times 4.6 \mathrm{~mm}$, ID), a $5 \mu \mathrm{m}$ reversed-phase C18 guard column $\left(50 \times 4.6 \mathrm{~mm}\right.$, ID) $\left(\right.$ Ascentis ${ }^{\circledR}$, Bellefonte, PA, USA), and a fluorescence detector model RF-10AXL (Shimadzu ${ }^{\circledR}$, Kyoto, $\mathrm{JPN})$. The mobile phase $\left(1.3 \mathrm{~mL} \cdot \mathrm{min}^{-1}\right)$ was $15 \mathrm{mmol} \cdot \mathrm{L}^{-1}$ sodium phosphate buffer ( $\mathrm{pH} 7.5)$ and methanol (50:50, v/v) at a gradient elution.

2.7. Colorimetric Analyses. Urea and creatinine levels in urine and serum cortisol were determined by colorimetric methods in 96-well plates (absorbance at $570 \mathrm{~nm}$ ) on a VICTOR ${ }^{\mathrm{TM}} \mathrm{X} 4$ spectrophotometer (PerkinElmer ${ }^{\circledR}, \mathrm{MA}$, USA), using commercially available kits, as follows: Urea Assay Kit MAK006, Creatinine Assay Kit MAK080, and Cortisol ELISA SE120037, purchased from Sigma-Aldrich ${ }^{\circledR}$ Chemical Co, MO, USA.

Capillary blood glucose and lactate were analyzed within $30 \mathrm{~s}$ after collection on a Yellow Springs Instrument (YSI Life Sciences Inc, OH, USA).

2.8. Beetroot-Based Nutritional (BET) and PLA Gels. Beetroots belonging to the Chenopodiaceae family and Beta vulgaris $L$. species were purchased at a local market in Rio de Janeiro city (Southeastern Brazil - $22^{\circ} 54^{\prime} \mathrm{S} 43^{\circ} 10^{\prime} \mathrm{W}$ ). The gels formulation was produced as previously described [9]. Beetroots were washed in tap water, sanitized with a chlorine solution, and put into a centrifuge blender (model CE700, Black \& Decker $\left.{ }^{\circledR}\right)$. The juice produced has $91.55 \pm 0.75 \%$ of moisture and it was stored at $-20^{\circ} \mathrm{C}$ for further use. Also, other beetroots were washed in tap water, sanitized with a chlorine solution, sliced (3-8 $\mathrm{cm}$ wide and $2-4 \mathrm{~mm}$ thick), frozen at $-20^{\circ} \mathrm{C}$ for $48 \mathrm{~h}$, and freeze dried in a Liotop P1040 model (Liobras, São Paulo, Brazil). Then, these beetroots were crushed in a portable blender (Blender Pratic ${ }^{\circledR}$ cadence) to produce beetroot powder. To produce $100 \mathrm{~g}$ of BET, $90 \mathrm{~mL}$ of beetroot juice was mixed with $16.8 \mathrm{~g}$ of beetroot powder, $2.8 \mathrm{~g}$ of carboxymethylcellulose (C4888 Sigma-Aldrich Co, MO, USA), and $1 \mathrm{~mL}$ of artificial orange flavor.

The PLA was prepared by depleting the $\mathrm{NO}_{3}{ }^{-}$from the beetroot juice in a $\mathrm{NO}_{3}{ }^{-}$specific A-520E anion-exchange resin (Purolite ${ }^{\circledR}, \mathrm{PA}, \mathrm{USA}$ ). After $1 \mathrm{~h}$ on an orbital shaker, the juice suspension was loaded onto a sterile chromatography glass column $(3 \mathrm{~cm} \times 55 \mathrm{~cm}$, ID) and eluted with a vacuum pump. Fuji apple (Malus pumila species) puree was prepared by liquefying the apples in a portable blender (Cadence Co, RS, BR). To produce $100 \mathrm{~g}$ of PLA gel, $90 \mathrm{~mL}$ of $\mathrm{NO}_{3}{ }^{-}$ depleted beetroot juice, $16.8 \mathrm{~g}$ of apple puree (in substitution of beet chips), $2.8 \mathrm{~g}$ of carboxymethylcellulose, and $1 \mathrm{~mL}$ of artificial orange flavor were mixed.

2.9. Dietary $\mathrm{NO}_{3}{ }^{-}$and $\mathrm{NO}_{2}{ }^{-}$Contents of BET and PLA Gels. Analyses of $\mathrm{NO}_{3}{ }^{-}$and $\mathrm{NO}_{2}{ }^{-}$contents of gels were performed by weighing $1 \mathrm{~g}$ of gel samples and then dissolving in $8 \mathrm{~mL}$ of water. Samples were filtered through a $0.45 \mu \mathrm{m}$ cellulose membrane filter (MF Millipore ${ }^{\circledR}$, Darmstadt, GER); $\mathrm{NO}_{3}{ }^{-}$ and $\mathrm{NO}_{2}{ }^{-}$analyses were performed as previously described [8] using HPLC. All samples were analyzed in triplicate $(4 \times$ 3 ) and the results were expressed in mmol of $\mathrm{NO}_{2}^{-} \cdot 100 \mathrm{~g}^{-1}$ and $\mathrm{NO}_{3}{ }^{-} \cdot 100 \mathrm{~g}^{-1}$.

2.10. Statistical Analyses. All assumptions for using parametric tests were verified. The normality of all data was tested by the Shapiro-Wilk test. One-way (ANOVA) analysis of variance was performed with repeated measures to identify differences in the dietary $\mathrm{NO}_{2}{ }^{-}$and $\mathrm{NO}_{3}{ }^{-}$contents between BET and PLA gels. Analyses of cortisol, HR, and RQ between PLA and BET treatments were assessed using two-factor repeated measures ANOVA $2 \times 3$ for condition $\times$ time, of data collection $(0, \mathrm{AE},+20 \mathrm{~min})$. Analysis of Borg scale was conducted using one-factor repeated measures ANOVA to establish differences between conditions. Differences in urinary $\mathrm{NO}_{2}{ }^{-}$and $\mathrm{NO}_{3}{ }^{-}$, urea, creatinine, and $\mathrm{BP}$ (systolic and diastolic) between PLA and BET treatments were assessed using two-factor repeated measures ANOVA $2 \times 5$ for condition $\times$ time, of data collection $(0,60,90, \mathrm{BE}, \mathrm{AE},+20$, min). Analyses of lactate and blood glucose, between PLA and BET treatments, were assessed using two-factor repeated measures ANOVA $2 \times 4$ for condition $\times$ time, of data collection $(0$, $90, \mathrm{BE}, \mathrm{AE},+20 \mathrm{~min})$. Post hoc analysis of significant withinsubject effects was performed with adjustments for multiple comparisons using the Bonferroni correction. Differences in exercise time and $\mathrm{VO}_{2}$ were analyzed using two-tailed, paired samples $t$-tests. The null hypothesis was rejected when $p<$ 0.05. Statistical procedures were completed using Graphpad Prisma for windows version 5.

\section{Results}

3.1. $\mathrm{Gel} \mathrm{NO}_{2}{ }^{-}$and $\mathrm{NO}_{3}{ }^{-}$Contents. The $\mathrm{NO}_{3}{ }^{-}$content of PLA and BET were $0.33 \pm 0.15$ and $9.92 \pm 1.97 \mathrm{mmol} \cdot 100 \mathrm{~g}^{-1}$ $(p=0.014)$, respectively. $\mathrm{NO}_{2}{ }^{-}$content was insignificant $\left(<10 \mu \mathrm{mol} \cdot 100 \mathrm{~g}^{-1}\right)$ in both BET and PLA gels. The gels were well tolerated and only beeturia (red urine) was reported. This condition does not represent any health problem and is expected in studies of this nature. After the study period, the volunteers did not report beeturia anymore.

3.2. NO Synthesis. Urinary $\mathrm{NO}_{2}{ }^{-}$concentrations were significantly higher after BET ingestion when compared to PLA treatment, before the exercise, $\mathrm{BE}(0.049 \pm 0.018$ versus $0.001 \pm 0.000 \mathrm{mmol} \cdot \mathrm{mmol}^{-1}$ creatinine $)$, and even after exercise, $\mathrm{AE}\left(0.027 \pm 0.011\right.$ versus $0.001 \pm 0.000 \mathrm{mmol} \cdot \mathrm{mmol}^{-1}$ 
TABle 1: Physical performance on the treadmill test: $\mathrm{VO}_{2}$ and time (s) after nutritional intervention with the BET and PLA gel supplementations.

\begin{tabular}{lcc}
\hline Men and women & BET & PLA \\
\hline & \multicolumn{2}{c}{ Moderate intensity } \\
Baseline $\mathrm{VO}_{2}\left(\mathrm{~L} \cdot \mathrm{min}^{-1}\right)$ & $1.43 \pm 0.47$ & $1.40 \pm 0.44$ \\
Endpoint $\mathrm{VO}_{2}\left(\mathrm{~L} \cdot \mathrm{min}^{-1}\right)$ & $2.85 \pm 0.65$ & $2.89 \pm 0.78$ \\
& \multicolumn{2}{c}{ Severe intensity } \\
Baseline $\mathrm{VO}_{2}\left(\mathrm{~L} \cdot \mathrm{min}^{-1}\right)$ & $2.88 \pm 0.64$ & $2.92 \pm 0.81$ \\
Peak $\mathrm{VO}_{2 \text { peak }}\left(\mathrm{L} \cdot \mathrm{min}^{-1}\right)$ & $3.93 \pm 0.84$ & $4.00 \pm 0.95$ \\
Time (s) & $395.4 \pm 179.60$ & $390.90 \pm 158.50$ \\
\hline
\end{tabular}

Values are presented as mean \pm SD. BET, beetroot gel $(9.92 \pm$ $\left.1.97 \mathrm{mmol} \cdot 100 \mathrm{~g}^{-1}\right)$; PLA, placebo gel $\left(0.33 \pm 0.15 \mathrm{mmol} \cdot 100 \mathrm{~g}^{-1}\right) ; \mathrm{VO}_{2}$, oxygen volume.

creatinine) (Figure 2(a)). The $\mathrm{NO}_{2}^{-}$peak concentration occurred at $90 \mathrm{~min}$, in $\mathrm{BE}\left(0.049 \pm 0.018 \mathrm{mmol} \cdot \mathrm{mmol}^{-1}\right.$ creatinine), after supplementation and it was maintained until the end of the exercise. Urinary $\mathrm{NO}_{3}{ }^{-}$concentration concentrations were significantly higher in the BET when compared to PLA treatment, $\mathrm{BE}(1.91 \pm 1.43$ versus $0.79 \pm$ $0.47 \mathrm{mmol} \cdot \mathrm{mmol}^{-1}$ creatinine), $\mathrm{AE}(3.03 \pm 2.66$ versus $1.01 \pm$ $1.34 \mathrm{mmol} \cdot \mathrm{mmol}^{-1}$ creatinine $)$, and $+20(1.81 \pm 2.12$ versus $0.63 \pm 0.56 \mathrm{mmol} \cdot \mathrm{mmol}^{-1}$ creatinine) (Figure 2(b)).

3.3. Exercise Performance, $B P, R Q, H R$, and RPE. A single dose of BET did not promote significant differences in $\mathrm{VO}_{2 \text { peak }}$ and time to fatigue when compared with PLA (Table 1). Systolic and diastolic BP did not differ significantly at any of the investigated time points (Figures 2(c) and 2(d)). Systolic BP was significantly higher after the BET and PLA treatments $\mathrm{AE}(133 \pm 24.8$ and $137 \pm 21.2 \mathrm{mmHg})$ when compared to T0 $(107 \pm 13.7$ and $110 \pm 12.4 \mathrm{mmHg})$, T60 $(108 \pm 14.7$ and $110 \pm 13.0 \mathrm{mmHg}), \mathrm{BE}(107 \pm 15.3$ and $110 \pm$ $11.6 \mathrm{mmHg})$, and $+20(107 \pm 15.6$ and $107 \pm 9.8 \mathrm{mmHg})$. RQ, $\mathrm{HR}$, and RPE measurements increased linearly with exercise intensity but did not differ significantly between BET and PLA treatments (Table 2).

3.4. Glucose and Lactate Concentration. Blood glucose concentrations were $11 \%$ higher $(p<0.05) \mathrm{AE}(111.59 \pm$ $\left.24.25 \mathrm{mg} \cdot \mathrm{dL}^{-1}\right)$ and $+20\left(93.95 \pm 19.32 \mathrm{mg} \cdot \mathrm{dL}^{-1}\right)$ for the PLA compared to BET supplementation $\mathrm{AE}(101.00 \pm 21.79$ and $+20: 80.79 \pm 18.11 \mathrm{mg} \cdot \mathrm{dL}^{-1}$ ) (Figure 2(e)). Blood lactate did not differ between the treatments at any of the investigated time points (Figure $2(\mathrm{f})$ ).

3.5. Cortisol Concentration. Serum cortisol concentrations before and after BET and PLA treatments did not differ between both treatments $(p=0.508)$ at any of the time points, although this hormone behaved as expected after exercise (Figure $2(\mathrm{~g}))$. Times T0 (131.15 \pm 83.38 and $127.22 \pm$ $\left.89.70 \mathrm{mg} \cdot \mathrm{mL}^{-1}\right)$ and $\mathrm{AE}(164.27 \pm 120.02$ and $131.44 \pm$ $84.22 \mathrm{mg} \cdot \mathrm{mL}^{-1}$ ) showed significantly lower contents than +20 $\left(281.38 \pm 138.54\right.$ and $\left.287.90 \pm 131.14 \mathrm{mg} \cdot \mathrm{mL}^{-1}\right)$ in both BET and PLA supplementations, respectively.
3.6. Urea Concentration. Urinary urea contents $(p=0.25)$ in BET and PLA treatments showed no significant differences in any time points. Urea levels were increased 3.6-4 fold after exercise (AE) but recovered to baseline levels (T0) after 20 min after both treatments (Figure 2(h)).

\section{Discussion}

Technological processes applied to foods can be advantageous to preserve, transport, store, and increase the nutritional value due to the concentration of compounds and nutrients. Foods in gel form are easier to drink and tolerable for endurance athletes before, during, and after exercise. The new formulated gels are composed of carbohydrates, fibers, saponins, and phenolic compounds (which contribute to their high antioxidant activity) and display adequate rheological properties, such as high viscosity, pleasant texture, and good consumer acceptance. Furthermore, the effect of BET has already been tested as an acute dietary $\mathrm{NO}_{3}{ }^{-}$supplement with effects on NO synthesis and BP in five healthy subjects, where BET increased plasma $\mathrm{NO}_{2}{ }^{-}$by 3 fold and decreased systolic and diastolic BP and HR after 60 min of ingestion [9]. Because of the advantages and beneficial effects related to food in gel form, the present study was developed with the objective of evaluating the effect of a single dose of nutritional BET gel rich in dietary $\mathrm{NO}_{3}{ }^{-}$on the biochemical, metabolic changes, and performance on the practice of endurance sports.

Herein, a single dose of $100 \mathrm{~g}$ of BET gel was shown to increase final urinary $\mathrm{NO}$ metabolites, $\mathrm{NO}_{3}{ }^{-}$, and $\mathrm{NO}_{2}{ }^{-}$, following exercise. However, after $100 \mathrm{~g}$ of PLA gel ingestion, no changes were observed in urinary $\mathrm{NO}_{3}{ }^{-}$and $\mathrm{NO}_{2}{ }^{-}$ concentrations. When it was ingested, dietary $\mathrm{NO}_{3}{ }^{-}$is readily absorbed across the upper gastrointestinal tract, about $60 \%$ of $\mathrm{NO}_{3}{ }^{-}$is excreted in the urine, and $25 \%$ is absorbed by salivary glands. In the oral cavity, the $\mathrm{NO}_{3}{ }^{-}$is reduced to $\mathrm{NO}_{2}{ }^{-}$by $\mathrm{NO}_{3}{ }^{-}$-reductase enzyme. After being swallowed, the $\mathrm{NO}_{2}{ }^{-}$is decomposed nonenzymatically to NO. In aqueous solutions, $\mathrm{NO}$ undergoes rapid oxidation to $\mathrm{NO}_{2}{ }^{-}$without the presence of oxyhemoproteins and thus $\mathrm{NO}_{2}{ }^{-}$is the main product of $\mathrm{NO}$ decomposition $[5,11]$. Therefore, it was expected the increase in urinary $\mathrm{NO}_{3}{ }^{-}$concentration after BET and not in PLA gel ingestion because PLA gel had the dietary $\mathrm{NO}_{3}{ }^{-}$removed. Also, that is because the urinary $\mathrm{NO}_{2}{ }^{-}$concentration only increased after BET gel ingestion. For this reason, many studies have used urinary $\mathrm{NO}$ metabolites as an index of $\mathrm{NO}$ synthesis because $\mathrm{NO}_{2}{ }^{-}$is metabolic end product derived from $\mathrm{NO}$ oxidation in plasma and subsequently excreted in urine [26].

The main finding of the present study is that despite increased NO synthesis after $100 \mathrm{~g}$ of BET gel ingestion no improvement in physical performance was observed, assessed by the reduction of $\mathrm{VO}_{2 \text { peak }}$ and increase time to fatigue. This is in accordance with previous results, where the effects of a single and short-term (3-5 days) dose of $\mathrm{NO}_{3}{ }^{-}$rich beetroot juice $[27,28]$ showed a very limited effect on $\mathrm{VO}_{2}$ and no improvements in physical performance. Arnold et al., [22] demonstrated that acute beetroot juice supplementation with $7 \mathrm{mmol}$ of $\mathrm{NO}_{3}{ }^{-}$did not promote any effect on $\mathrm{VO}_{2 \text { peak }}$ 


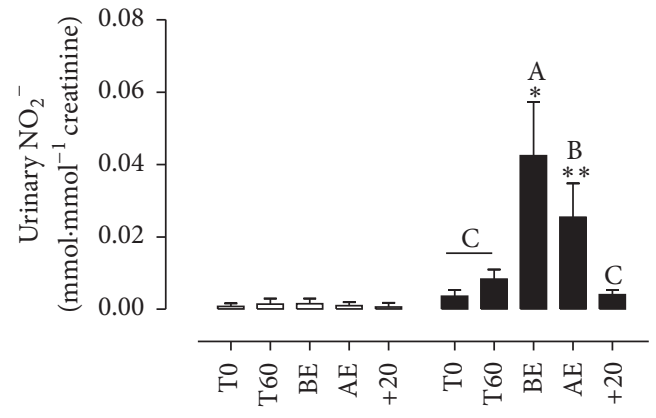

(a)

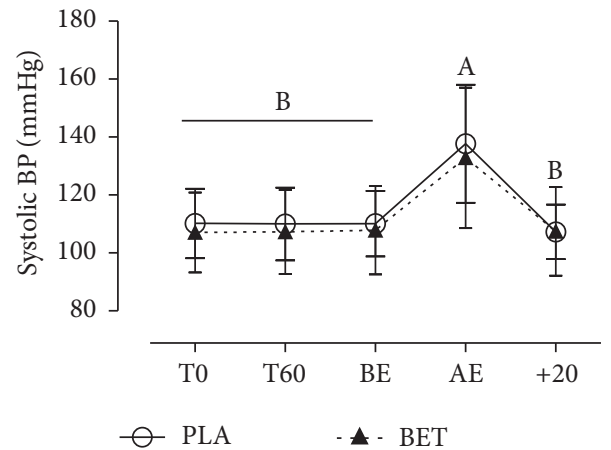

(c)

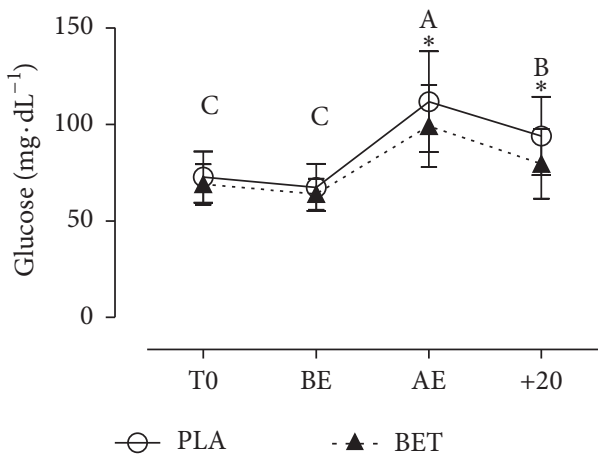

(e)

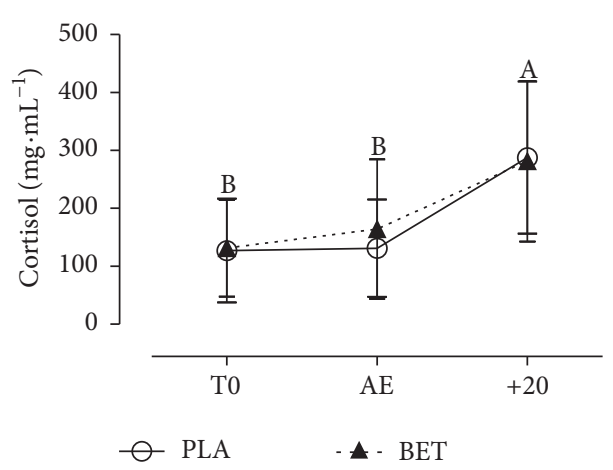

(g)

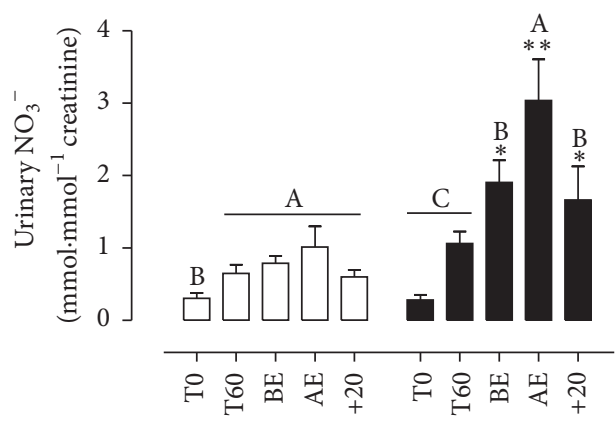

(b)

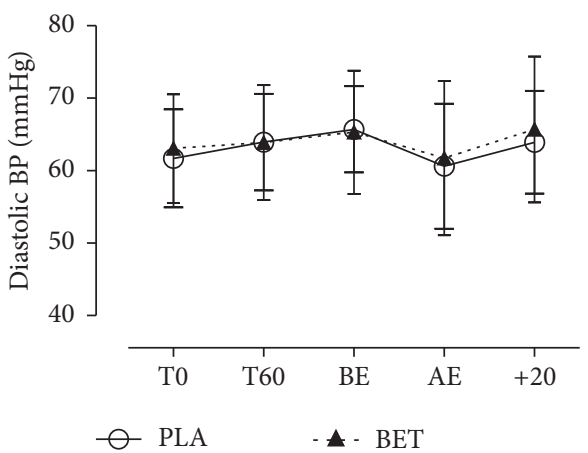

(d)

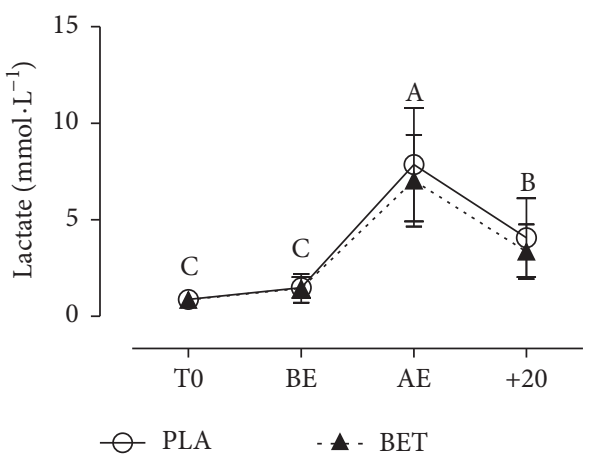

(f)

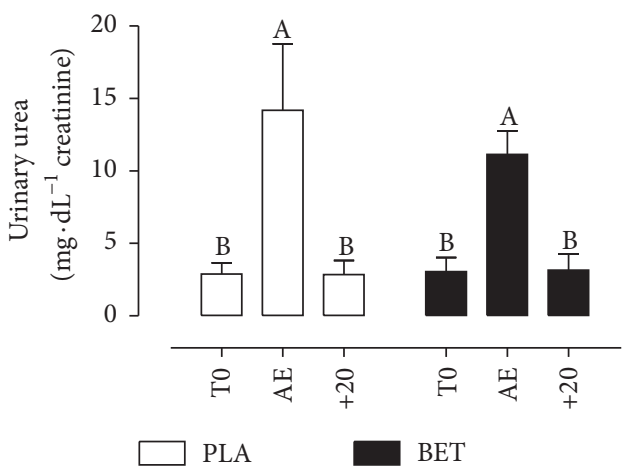

(h)

FIGURE 2: Urinary $\mathrm{NO}_{2}{ }^{-}$(a) and $\mathrm{NO}_{3}{ }^{-}$(b) concentrations, systolic (c) and diastolic (d) blood pressures, blood glucose (e), lactate (f), serum cortisol (g), and (h) urinary urea taken at the baseline (T0), 60 min after gel ingestion (T60), before exercise (BE), after exercise (AE), and $20 \mathrm{~min}$ after the end of the exercise $(+20)$. The $\operatorname{symbol}^{*}(p<0.05)$ indicates significant difference compared to the PLA treatment. The symbol ${ }^{* *}(p<0.001)$ indicates significant difference compared to the PLA treatment. Different letters denote statistical significance within the same treatment in different time intervals at $p<0.05$. Values are presented as mean $\pm \mathrm{SD}$ for urinary $\mathrm{NO}_{2}{ }^{-}, \mathrm{NO}_{3}{ }^{-}$, blood glucose, lactate, cortisol, urea, and mean \pm SEM for hemodynamic parameters. 
TABLE 2: Physiological responses at moderate and severe intensities after the nutritional intervention with the BET and PLA gel supplementations.

\begin{tabular}{|c|c|c|c|c|c|}
\hline Men and women & Group & Warm up & Moderate & Peak (severe) & $p$ \\
\hline \multirow{2}{*}{ RQ } & PLA & $0.77 \pm 0.05$ & $0.91 \pm 0.05$ & $0.97 \pm 0.06$ & $<0.0001$ \\
\hline & BET & $0.78 \pm 0.06$ & $0.91 \pm 0.05$ & $0.97 \pm 0.06$ & $<0.0001$ \\
\hline \multirow{2}{*}{ HR (bpm) } & PLA & $98.46 \pm 12.12$ & $150.58 \pm 11.81$ & $179.58 \pm 7.50$ & $<0.0001$ \\
\hline & BET & $97.50 \pm 10.92$ & $150.85 \pm 12.02$ & $180.92 \pm 10.88$ & $<0.0001$ \\
\hline \multirow{2}{*}{ RPE (Borg) } & PLA & $1.08 \pm 0.28$ & $4.12 \pm 1.30$ & $10.00 \pm 0.00$ & $<0.0001$ \\
\hline & BET & $1.08 \pm 0.28$ & $4.12 \pm 1.24$ & $9.88 \pm 0.60$ & $<0.0001$ \\
\hline
\end{tabular}

Values are presented as mean \pm SD. BET, beetroot gel $\left(9.92 \pm 1.97 \mathrm{mmol} \cdot 100 \mathrm{~g}^{-1}\right)$; PLA, placebo gel $\left(0.33 \pm 0.15 \mathrm{mmol} \cdot 100 \mathrm{~g}^{-1}\right)$; RQ, respiratory quotient; HR, heart rate; RPE, rating of perceived exertion.

and RPE after incremental exercise to exhaustion at $4000 \mathrm{~m}$ and a $10 \mathrm{~km}$ treadmill time-trial at $2500 \mathrm{~m}$ simulated altitude in well-trained competitive male runners. Also, Vanhatalo et al., [21] demonstrated that acute beetroot juice supplementation with $\sim 5.2 \mathrm{mmol}$ of $\mathrm{NO}_{3}{ }^{-}$did not promote any effect on $\mathrm{VO}_{2 \text { peak }}$ and GET in volunteers physically active. However, the same sodium $\mathrm{NO}_{3}{ }^{-}\left(\mathrm{NaNO}_{3}{ }^{-}\right)$supplementation $\left(0.1 \mathrm{mmol} \cdot \mathrm{kg}^{-1} \cdot \mathrm{day}^{-1}\right)$ for 3 days reduced $\mathrm{VO}_{2}$ during submaximal cycling exercise in untrained men [29]. Beyond that, in a recent systematic review and meta-analysis [30], benefits on physical performance have been suggested as being more often and meaningful in healthy inactive individuals, rather than active individuals. This lack of positive results in physical performance observed herein and in the aforementioned studies conducted on volunteers welltrained for endurance can be explained by the physiological adaptations of endurance training that may play a role in increasing NO bioavailability by stimulating the expression and activity of NOS enzyme through the endogenous pathway (via L-arginine/NO) [31]. Due to the activation of the enzyme, the dependency of NO bioavailability derived from dietary $\mathrm{NO}_{3}{ }^{-}$supplementation could be reduced. Comparing trained and untrained subjects, the trained ones are less prone to experience a low oxygen and muscle acidosis, which are favorable for the reduction of $\mathrm{NO}_{3}{ }^{-}$to $\mathrm{NO}$ [32]. Therefore, any further stimulus for NO synthesis (like the $\mathrm{NO}_{3}{ }^{-}-\mathrm{NO}_{2}{ }^{-}$/NO pathway) can be reduced because of the high capacity of NO synthesis thought efficient endogenous pathways present in highly endurance-trained individuals.

Improvement in the physical performance of healthy active well-trained individuals was observed by the majority of studies, which offered long-term (6 or more days) beetroot supplementation with doses varying between 5.0 and $11.2 \mathrm{mmol}$ of $\mathrm{NO}_{3}{ }^{-}[15,19,21,29]$. However, the precise mechanism by which $\mathrm{NO}_{3}{ }^{-}$supplementation reduced $\mathrm{VO}_{2}$, implying improved muscle efficiency and enhanced exercise tolerance during physical activity, has not yet been elucidated. Given the multifarious roles of NO in physiology, it is not surprising that there are several possible explanations for the reported systemic effects of $\mathrm{NO}$ from $\mathrm{NO}_{3}{ }^{-}$supplementation. Once synthesized NO can operate as a regulator of cellular $\mathrm{O}_{2}$ utilization increasing mitochondrial efficiency. The NO can then bind to $\mathrm{O}_{2}$ receptors, inhibiting the cytochrome c oxidase enzyme (complex terminal mitochondrial respiratory chain). Through inhibition of this enzyme, NO modulates intracellular and tissue $\mathrm{O}_{2}$ distribution [33]. In addition, $\mathrm{NO}$ may reduce the leakage of protons, attenuating the expression of uncoupled proteins, and thus increasing the oxidative phosphorylation efficiency [34]. Furthermore, decreases in $\mathrm{O}_{2}$ consumption can be attributed to the reduced ATP expenditure necessary to increase muscle contractile efficiency. During skeletal muscle contraction, the calcium pumping from the sarcoplasmic reticulum requires increased energy expenditure, and $\mathrm{NO}$ generated from $\mathrm{NO}_{3}{ }^{-}$supplementation can increase the stoichiometric efficiency of the calcium-ATPase enzyme of the sarcoplasmic reticulum, increasing calcium transportation efficiency or preventing excess calcium release and reducing the energy consumption of its reuptake [34].

Aerobically trained individuals have specific physiological adaptations that may limit possible benefits from $\mathrm{NO}_{3}{ }^{-}$ supplementation. Also, one cannot exclude the possibility of "responsive" and "nonresponsive" individuals to $\mathrm{NO}_{3}{ }^{-}$ supplementation. Regarding systolic/diastolic BP and HR, no significant decrease was observed after the BET treatment. These results are in agreement with previous reports that found no significant changes in BP and HR in well-trained competitive male runners and recreationally fit volunteers after a single dose of beetroot juice and roasted beetroot containing 7 and $8 \mathrm{mmol}$ of $\mathrm{NO}_{3}{ }^{-}[18,22]$. However, studies in healthy but untrained subjects verified systolic BP reduction after a single $\mathrm{NO}_{3}{ }^{-}$supplementation from beetroot $[9,21$, 35]. It seems that, beyond the influence of acute versus chronic $\mathrm{NO}_{3}{ }^{-}$supplementation (4-6 days), physical fitness may negate the effects of dietary $\mathrm{NO}_{3}{ }^{-}$supplementation on $\mathrm{BP}$, as quoted above.

The positive effect of $\mathrm{NO}_{3}{ }^{-}$supplementation on lowering blood glucose was observed in the present study after exercising and during exercising recovery. Furthermore, as expected during high exercise intensity, blood lactate was increased in BET and PLA gels treatments. But, the lactate concentration did not differ significantly in BET and PLA gels at any time point, indicating that the aerobic exercise intensity was the same for both treatments. These findings corroborate previous studies [18] that also described lower plasma glucose in high intensity and intermittent exercise after beetroot juice supplementation $\left(\sim 8.2 \mathrm{mmol}\right.$ of $\left.\mathrm{NO}_{3}{ }^{-}\right)$but no changes in lactate levels. NO plays a key role in the regulation of glucose uptake in contracting skeletal muscles by decreasing blood 
glucose during exercise, as GLUT4 translocation is enhanced [36].

As observed for blood lactate levels, urinary urea and serum cortisol concentrations did not differ significantly after BET and PLA gel ingestion. A late urea increment after $24 \mathrm{~h}$ could be expected, as observed after a $100 \mathrm{~km}$ race study [37]. No modifications in urea levels are expected after BET ingestion, since there was no protein intake during BET and PLA visits, eliminating interferences in the urea excretion in volunteers.

\section{Conclusion}

The new beetroot nutritional gel was successfully developed as a $\mathrm{NO}_{3}{ }^{-}$supplement for athletes and showed to be advantageous for athletes as a replacement for sport drinks in order to avoid possible gastric discomfort due to the ingestion of large volume. Also, the gel is also easier to be transported and more appropriate to be consumed in sport events.

A single dose of this beetroot gel promoted an increased in the excretion of metabolites related to NO synthesis and promoted lower the plasma glucose immediately after exercise and during exercise recovery. However, the beetroot gel did not enhance the physical performance during aerobic submaximal exercise or cause changes in serum cortisol and blood lactate levels in recreational athletes. These results raise the question of the ergogenic potential of $\mathrm{NO}_{3}{ }^{-}$to increase performance acutely in recreational athletes. Further acute $\mathrm{NO}_{3}{ }^{-}$ingestion studies with more comprehensive data are needed to clarify if the $\mathrm{NO}_{3}{ }^{-}$can actually improve physical performance in well-trained athletes.

\section{Competing Interests}

The authors declare that they have no conflict of interests.

\section{Acknowledgments}

The authors would like to acknowledge the financial support and fellowships from the Fundação de Amparo à Pesquisa do Estado do Rio de Janeiro-FAPERJ and the Coordenação de Aperfeiçoamento de Pessoal de Nível Superior-CAPES and LioFoods ${ }^{\circledR}$ from São Paulo, Brazil, for providing the beetroot chips.

\section{References}

[1] D. M. Ahrendt, "Ergogenic aids: counseling the athlete," American Family Physician, vol. 63, no. 5, pp. 913-922, 2001.

[2] R. D. Burns, M. R. Schiller, M. A. Merrick, and K. N. Wolf, "Intercollegiate student athlete use of nutritional supplements and the role of athletic trainers and dietitians in nutrition counseling," Journal of the American Dietetic Association, vol. 104, no. 2, pp. 246-249, 2004.

[3] W. T. Clements, S.-R. Lee, and R. J. Bloomer, "Nitrate ingestion: a review of the health and physical performance effects," Nutrients, vol. 6, no. 11, pp. 5224-5264, 2014.

[4] B. M. Malinauskas, R. F. Overton, V. G. Carraway, and B. C. Cash, "Supplements of interest for sport-related injury and sources of supplement information among college athletes," Advances in Medical Sciences, vol. 52, pp. 50-54, 2007.

[5] D. d. Baião, C. A. Conte, J. T. Silva, V. M. Paschoalin, and T. S. Alvares, "L-arginine supplementation and nitric oxide production:no additional effect when associated to exercise," Food and Nutrition Sciences, vol. 4, no. 8, pp. 779-784, 2013.

[6] N. S. Bryan and J. L. Ivy, "Inorganic nitrite and nitrate: evidence to support consideration as dietary nutrients," Nutrition Research, vol. 35, no. 8, pp. 643-654, 2015.

[7] J. O. Lundberg, E. Weitzberg, and M. T. Gladwin, "The nitratenitrite-nitric oxide pathway in physiology and therapeutics," Nature Reviews Drug Discovery, vol. 7, no. 2, pp. 156-167, 2008.

[8] D. dos Santos Baião, C. A. Conte-Junior, V. M. F. Paschoalin, and T. S. Alvares, "Quantitative and comparative contents of nitrate and nitrite in beta vulgaris $\mathrm{L}$. by reversed-phase high-performance liquid chromatography-fluorescence," Food Analytical Methods, vol. 9, no. 4, pp. 1002-1008, 2016.

[9] D. V. Silva, F. O. Silva, D. Perrone et al., "Physicochemical, nutritional, and sensory analyses of a nitrate-enriched beetroot gel and its effects on plasmatic nitric oxide and blood pressure," Food \& Nutrition Research, vol. 60, article 29909, 9 pages, 2016.

[10] J. Vasconcellos, C. Conte-Junior, D. Silva, A. P. Pierucci, V. Paschoalin, and T. S. Alvares, "Comparison of total antioxidant potential, and total phenolic, nitrate, sugar, and organic acid contents in beetroot juice, chips, powder, and cooked beetroot," Food Science and Biotechnology, vol. 25, no. 1, pp. 79-84, 2016.

[11] D. Dos Santos Baião, C. A. Conte-Junior, V. M. F. Paschoalin, and T. S. Alvares, "Beetroot juice increase nitric oxide metabolites in both men and women regardless of body mass," International Journal of Food Sciences and Nutrition, vol. 67, no. 1, pp. 40-46, 2016.

[12] K. Y. Stokes, T. R. Dugas, Y. Tang, H. Garg, E. Guidry, and N. S. Bryan, "Dietary nitrite prevents hypercholesterolemic microvascular inflammation and reverses endothelial dysfunction," American Journal of Physiology-Heart and Circulatory Physiology, vol. 296, no. 5, pp. H1281-H1288, 2009.

[13] V. Kapil, A. J. Webb, and A. Ahluwalia, "Inorganic nitrate and the cardiovascular system," Heart, vol. 96, no. 21, pp. 1703-1709, 2010.

[14] B. C. Breese, M. A. Mcnarry, S. Marwood, J. R. Blackwell, S. J. Bailey, and A. M. Jones, "Beetroot juice supplementation speeds $\mathrm{O}_{2}$ uptake kinetics and improves exercise tolerance during severe-intensity exercise initiated from an elevated metabolic rate," American Journal of Physiology-Regulatory Integrative and Comparative Physiology, vol. 305, no. 12, pp. R1441-R1450, 2013.

[15] N. M. Cermak, M. J. Gibala, and L. J. C. van Loon, "Nitrate supplementation's improvement of $10-\mathrm{km}$ time-trial performance in trained cyclists," International Journal of Sport Nutrition and Exercise Metabolism, vol. 22, no. 1, pp. 64-71, 2012.

[16] K. E. Lansley, P. G. Winyard, J. Fulford et al., "Dietary nitrate supplementation reduces the $\mathrm{O} 2$ cost of walking and running: a placebo-controlled study," Journal of Applied Physiology, vol. 110, no. 3, pp. 591-600, 2011.

[17] M. Murphy, K. Eliot, R. M. Heuertz, and E. Weiss, "Whole beetroot consumption acutely improves running performance," Journal of the Academy of Nutrition and Dietetics, vol. 112, no. 4, pp. 548-552, 2012.

[18] L. J. Wylie, M. Mohr, P. Krustrup et al., "Dietary nitrate supplementation improves team sport-specific intense intermittent exercise performance," European Journal of Applied Physiology, vol. 113, no. 7, pp. 1673-1684, 2013. 
[19] S. J. Bailey, P. Winyard, A. Vanhatalo et al., "Dietary nitrate supplementation reduces the $\mathrm{O} 2$ cost of low-intensity exercise and enhances tolerance to high-intensity exercise in humans," Journal of Applied Physiology, vol. 107, no. 4, pp. 1144-1155, 2009.

[20] C. Thompson, L. J. Wylie, J. Fulford et al., "Dietary nitrate improves sprint performance and cognitive function during prolonged intermittent exercise," European Journal of Applied Physiology, vol. 115, no. 9, pp. 1825-1834, 2015.

[21] A. Vanhatalo, S. J. Bailey, J. R. Blackwell et al., "Acute and chronic effects of dietary nitrate supplementation on blood pressure and the physiological responses to moderate-intensity and incremental exercise," American Journal of PhysiologyRegulatory Integrative and Comparative Physiology, vol. 299, no. 4, pp. R1121-R1131, 2010.

[22] J. T. Arnold, S. J. Oliver, T. M. Lewis-Jones, L. J. Wylie, and J. H. Macdonald, "Beetroot juice does not enhance altitude running performance in well-trained athletes," Applied Physiology, Nutrition and Metabolism, vol. 40, no. 6, pp. 590-595, 2015.

[23] F. A. Cunha, A. Midgley, W. D. Monteiro, and P. T. Farinatti, "Influence of cardiopulmonary exercise testing protocol and resting $\mathrm{VO}_{2}$ assessment on \%HRmax, \%HRR, \% $\mathrm{VO}_{2}$ max and $\% \mathrm{VO}_{2} \mathrm{R}$ relationships," International Journal of Sports Medicine, vol. 31, pp. 319-326, 2010.

[24] W. L. Beaver, K. Wasserman, and B. J. Whipp, "A new method for detecting anaerobic threshold by gas exchange," Journal of Applied Physiology, vol. 60, no. 6, pp. 2020-2027, 1986.

[25] G. Borg, Escalas de Borg para a dor e o esforço percebido, Editora Manole Ltda, São Paulo, Brazil, 1st edition, 2000.

[26] H. Suzuki, H. Ikenaga, K. Hishikawa, T. Nakaki, R. Kato, and T. Saruta, "Increases in $\mathrm{NO}_{2}^{-} / \mathrm{NO}_{3}^{-}$excretion in the urine as an indicator of the release of endothelium-derived relaxing factor during elevation of blood pressure," Clinical Science, vol. 82, no. 6, pp. 631-634, 1992.

[27] N. M. Cermak, P. Res, R. Stinkens, J. O. Lundberg, M. J. Gibala, and L. J. C. Van Loon, "No improvement in endurance performance after a single dose of beetroot juice," International Journal of Sport Nutrition and Exercise Metabolism, vol. 22, no. 6, pp. 470-478, 2012.

[28] J. Puype, M. Ramaekers, R. Van Thienen, L. Deldicque, and P. Hespel, "No effect of dietary nitrate supplementation on endurance training in hypoxia," Scandinavian Journal of Medicine and Science in Sports, vol. 25, no. 2, pp. 234-241, 2015.

[29] F. J. Larsen, E. Weitzberg, J. O. Lundberg, and B. Ekblom, "Effects of dietary nitrate on oxygen cost during exercise," Acta Physiologica, vol. 191, no. 1, pp. 59-66, 2007.

[30] M. W. Hoon, N. A. Johnson, P. G. Chapman, and L. M. Burke, "The effect of nitrate supplementation on exercise performance in healthy individuals: a systematic review and metaanalysis," International Journal of Sport Nutrition and Exercise Metabolism, vol. 23, no. 5, pp. 522-532, 2013.

[31] B. A. Kingwell, "Nitric oxide-mediated metabolic regulation during exercise: effects of training in health and cardiovascular disease," FASEB Journal, vol. 14, no. 12, pp. 1685-1696, 2000.

[32] D. P. Wilkerson, G. M. Hayward, S. J. Bailey, A. Vanhatalo, J. R. Blackwell, and A. M. Jones, "Influence of acute dietary nitrate supplementation on 50 mile time trial performance in welltrained cyclists," European Journal of Applied Physiology, vol. 112, no. 12, pp. 4127-4134, 2012.

[33] G. C. Brown and C. E. Cooper, "Nanomolar concentrations of nitric oxide reversibly inhibit synaptosomal respiration by competing with oxygen at cytochrome oxidase," FEBS Letters, vol. 356, no. 2-3, pp. 295-298, 1994.
[34] A. Zafeiridis, "The effects of dietary nitrate (beetroot juice) supplementation on exercise performance: a review," American Journal of Sports Science, vol. 2, no. 4, pp. 97-100, 2014.

[35] L. J. Wylie, J. Kelly, S. J. Bailey et al., "Beetroot juice and exercise: pharmacodynamic and dose-response relationships," Journal of Applied Physiology, vol. 115, no. 3, pp. 325-336, 2013.

[36] G. K. McConell, S. Rattigan, R. S. Lee-Young, G. D. Wadley, and T. L. Merry, "Skeletal muscle nitric oxide signaling and exercise: a focus on glucose metabolism," American Journal of Physiology-Endocrinology and Metabolism, vol. 303, no. 3, pp. E301-E307, 2012.

[37] J. Décombaz, P. Reinhardt, K. Anantharaman, G. von Glutz, and J. R. Poortmans, "Biochemical changes in a $100 \mathrm{~km}$ run: free amino acids, urea, and creatinine," European Journal of Applied Physiology and Occupational Physiology, vol. 41, no. 1, pp. 61-72, 1979. 


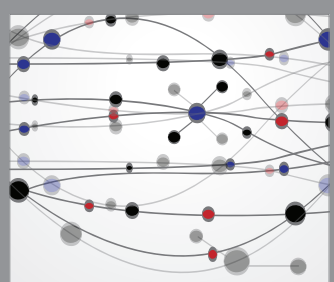

The Scientific World Journal
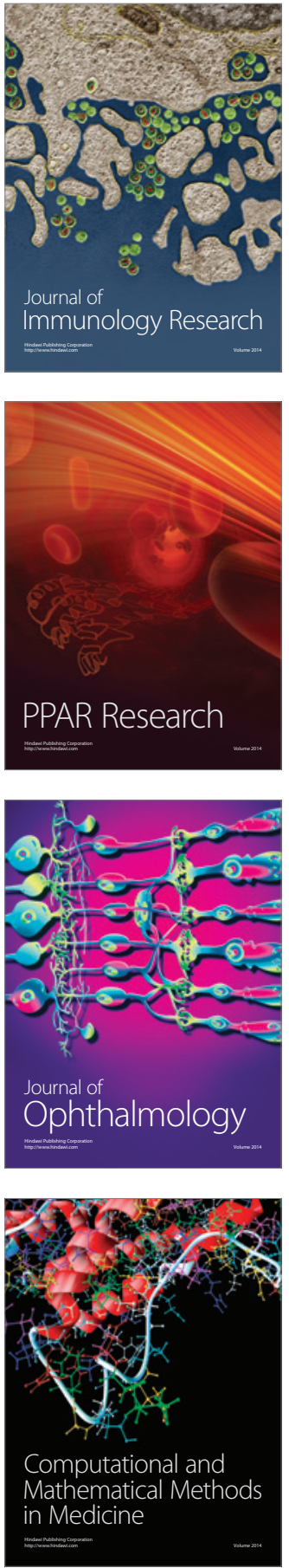

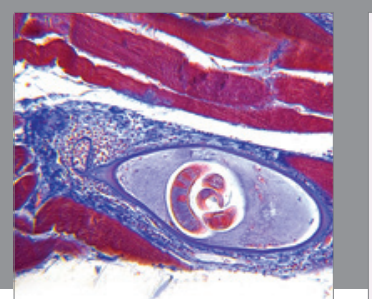

Gastroenterology Research and Practice
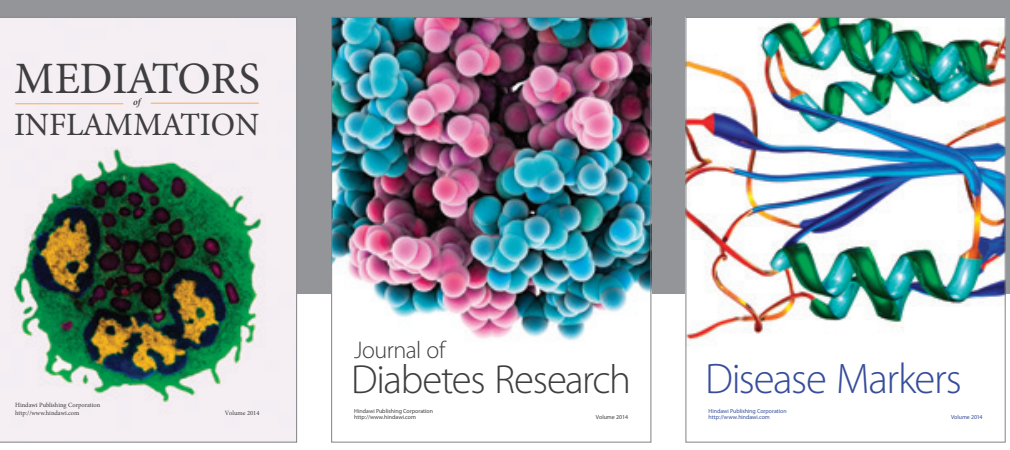

Disease Markers

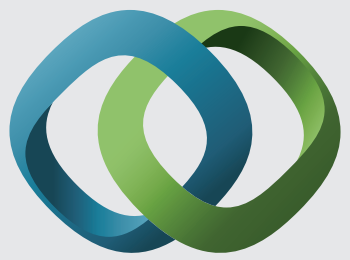

\section{Hindawi}

Submit your manuscripts at

https://www.hindawi.com
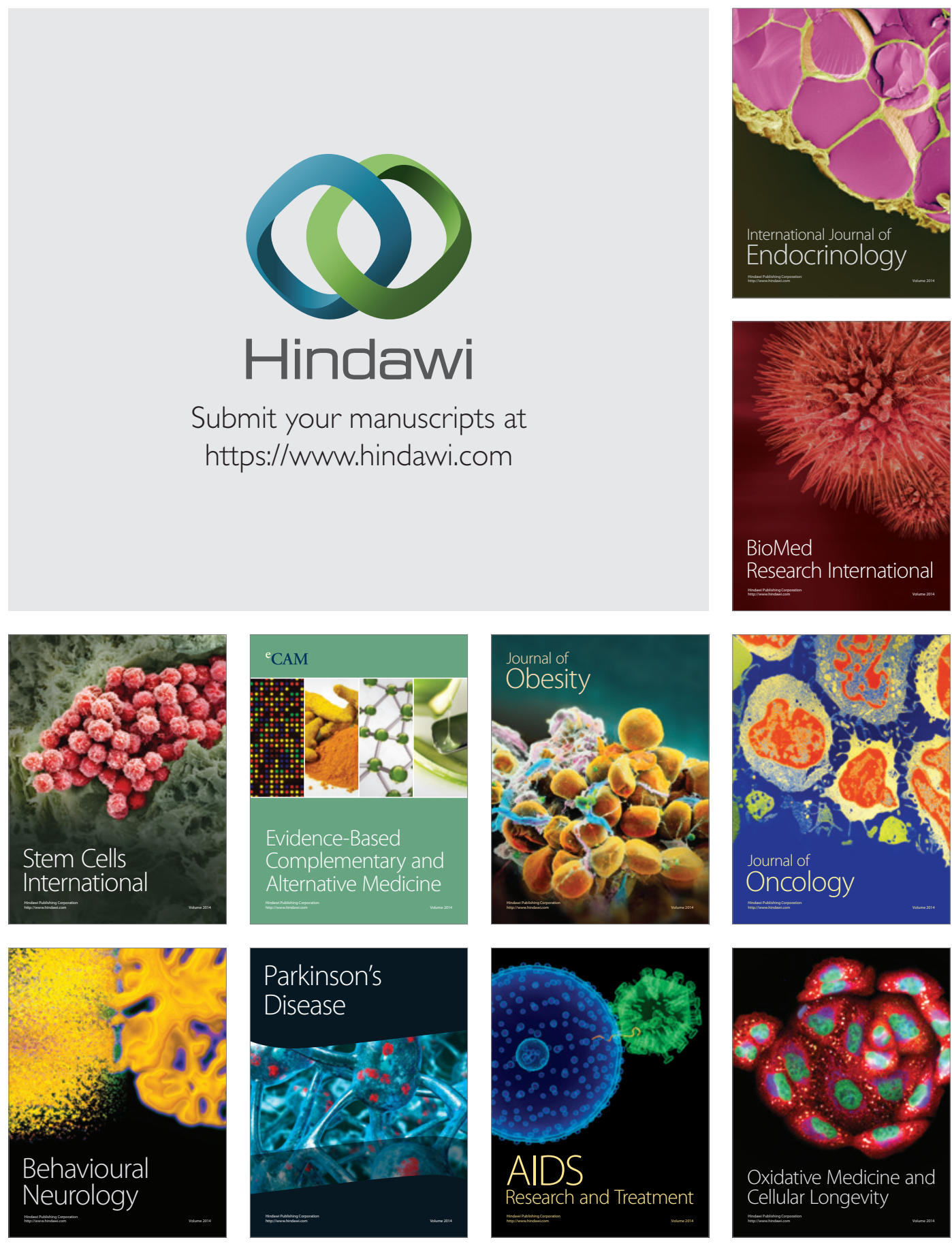